\title{
"Predictive value of accruals and the moderating role of company size: Empirical evidence from Jordan"
}

\begin{tabular}{|c|c|}
\hline AUTHORS & Mohammad Fawzi Shubita (iD) \\
\hline ARTICLE INFO & $\begin{array}{l}\text { Mohammad Fawzi Shubita (2021). Predictive value of accruals and the } \\
\text { moderating role of company size: Empirical evidence from Jordan. Investment } \\
\text { Management and Financial Innovations, 18(3), 142-150. } \\
\text { doi:10.21511/imfi.18(3).2021.13 }\end{array}$ \\
\hline DOI & http://dx.doi.org/10.21511/imfi.18(3).2021.13 \\
\hline RELEASED ON & Thursday, 19 August 2021 \\
\hline RECEIVED ON & Thursday, 10 June 2021 \\
\hline \multirow[t]{2}{*}{ ACCEPTED ON } & Thursday, 29 July 2021 \\
\hline & $((c)) \overline{E Y}$ \\
\hline LICENSE & $\begin{array}{l}\text { This work is licensed under a Creative Commons Attribution } 4.0 \text { International } \\
\text { License }\end{array}$ \\
\hline JOURNAL & "Investment Management and Financial Innovations" \\
\hline ISSN PRINT & $1810-4967$ \\
\hline ISSN ONLINE & $1812-9358$ \\
\hline PUBLISHER & LLC "Consulting Publishing Company "Business Perspectives" \\
\hline FOUNDER & LLC "Consulting Publishing Company "Business Perspectives" \\
\hline
\end{tabular}

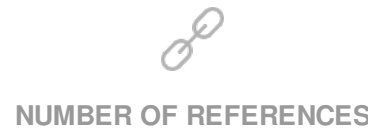

30
NUMBER OF FIGURES

0
NUMBER OF TABLES

4

(C) The author(s) 2021. This publication is an open access article. 


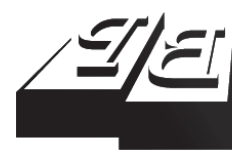

\section{BUSINESS PERSPECTIVES}

(2)

LLC "CPC "Business Perspectives" Hryhorii Skovoroda lane, 10, Sumy, 40022, Ukraine www.businessperspectives.org
Received on: $10^{\text {th }}$ of June, 2021 Accepted on: $29^{\text {th }}$ of July, 2021 Published on: $19^{\text {th }}$ of August, 2021

(c) Mohammad Fawzi Shubita, 2021

Mohammad Fawzi Shubita, Professor Head of Accounting Department, Amman Arab University, Jordan.
This is an Open Access article distributed under the terms of the Creative Commons Attribution 4.0 International license, which permits unrestricted re-use, distribution, and reproduction in any medium, provided the original work is properly cited.

Conflict of interest statement: Author(s) reported no conflict of interest

\title{
PREDICTIVE VALUE OF ACCRUALS AND THE MODERATING ROLE OF COMPANY SIZE: EMPIRICAL EVIDENCE FROM JORDAN
}

\begin{abstract}
The cash flow statement aids the management to ascertain the profitability and liquidity position of a company. One can understand from the cash flow statement how efficiently the company is paying its obligation in various forms of liability and expense. This study aimed to explore the ability of short-term accounting accruals to predict cash flows. The sample included 77 Jordanian companies listed between 2006-2019. Cash flows were measured by net operating cash flows, and short-term accounting accruals were expressed as: change in account receivable, change in accounts payable, change in inventories, and other accruals. The results demonstrated the ability of shortterm accounting accruals to predict future cash flows. The relationship between future cash flows and the short-term accounting accruals was significant, except for its relationship to the change in accounts payable. However, the findings indicate that the size of the company has not moderated the relationship between accounting accruals and operating cash flow. The study recommends using other accounting items besides short-term accounting accruals, to improve their ability to predict future cash flows and use of control variables that can increase the predictive power of the study model, such as financial leverage and company size.
\end{abstract}

Keywords

JEL Classification

\section{INTRODUCTION}

The statement of cash flow summarizes the amount of cash and cash equivalents leaving and entering a firm. The cash flow statement measures how well a company manages its cash position, meaning how well the company generates cash to fund its operating expenses and to pay its debt obligations.

Proper cash management is possible if the cash flow statement is properly prepared. The management can prepare a forecast about several inflows and outflows of cash so that it becomes very helpful for them to make plans for the future. Since the cash flow statement presents the cash position of a company at the time of making payment, it aids to ascertain the liquidity position, the same is also applicable in the case of profitability (Shubita, 2019). Cash flows from investing activities refer to the company's ability to expand. When the outflows are large, it means that the firm can expand. The financing flows refer to the management's ability to finance its activities, whether from internal or external sources (Dambra, 2018).

Accounting accruals are considered one of the most important items that reflect future cash flows, as they are adjustments to current cash flows. Accruals are needed for any revenue earned or expense incurred, 
for which cash has not yet been exchanged. Accruals improve the quality of information on financial statements by adding useful information about short-term credit extended to customers and upcoming liabilities owed to lenders. A distinction should be made between long-term and short-term accounting accruals. The criterion used to divide accruals to long- or short-term is the same as for any other liability or asset. That is if accrual is to remain on the balance sheet for more than a year after the balance sheet date, then it is classified as long-term accrual, otherwise, it is a short-term accrual. Accounting accruals are among the items that have been relied on to improve models for forecasting future cash flows. Accruals include all the elements that allow the transition from the cash basis to the accrual basis (Dechow et al., 1998).

The cash flow prediction concept is important for both academics and professionals; it helps users of financial statements to assess the financial risks, flexibility, and liquidity of a firm. Many studies gave evidence that income can better predict future operating cash flows than current operating cash flows (Nam et al., 2012; Kim \& Kross, 2005; Dechow et al., 1998). The income information is supported for several reasons. First, the matching between revenues and expenses to obtain accrual-based income reflects the use of assets in generating revenue. Second, it is considered relevant in measuring the company's performance because it avoids distortion of uncertain variations in cash flows in the performance measurement process (Godfrey et al., 2003; Luc, 2018). On the other hand, Board and Day (1989), Greenberg et al. (1986), and Efayena (2015) have affirmed the usefulness of accrual-based earnings for predicting the company's future operating cash flows.

The financial statement users focus on the expected future cash flows for making decisions because cash flows are a good indicator of the company's ability to fulfill its obligations and the extent of its ability to provide returns to various parties. Furthermore, it is a good basis for determining the current value of the company. In this case, the adequacy of the accounting information is determined by the extent of its ability to predict future cash flows.

The study problem is that the adoption of the cash flow statement to conduct additional financial analyzes enhances the beneficiary's ability to make a rational decision as it was prepared on a cash basis and not on an accrual basis as in other statements, as the cash flow statement discloses the real liquidity of the economic unit, which helps users of financial statements to measure the ability of the economic unit has to fulfill its obligations from private sources, and whether it needs external financing. Thus, the financial analysis based on the available financing instead of the list of cash flows gives enough time for the economic unit to study the alternatives from the trend to high-cost financing sources.

Therefore, the study problem can focus also on that some financial ratios, such as the liquidity ratio, may not be achieved in the foreseeable future. Therefore, the adoption of financial ratios that depend on the cash basis provides financial information based on actual amounts that have been achieved during the period, which reduces the uncertainty.

\section{LITERATURE REVIEW AND HYPOTHESES DEVELOPMENT}

Al Sharawi (2021) examined the role of earnings derived from accrual accounting in comparison with cash flows in the prediction of future operating cash flows of quoted non-financial companies in Egypt and Saudi Arabia. The results suggested that both cash flows and earnings have the predictive ability in predicting future cash flows in both countries. However, the results showed that cash flows are a better predictor of future operating cash flows than earnings in both countries. The study findings are in contrast to the assertion of the Financial Accounting Standards Board (FASB) and International Accounting Standards Board (IASB) that earnings are a better predictor of future cash flows. 
Machokoto and Areneke (2021) examined whether the operating cash flow sensitivity is asymmetric using a sample of 745 companies from African countries over the period from 2000 to 2015. The study affirmed that the asymmetry in the cash flow from operating activities sensitivity of cash and highlighted the severity of the impact of financial constraints on corporate decisions in emerging markets.

Ngatimo et al. (2021) determined the impact of current ratio, financial leverage, and cash flow on company market value in industrial companies in Indonesia. Using documentation as a collection technique, the findings were that cash flow had no impact on company market value in the beverages and food sector companies. On the other hand, the current ratio and financial leverage had a positive impact on company market value. Pimentel and Malacrida (2020) analyzed the informative content of quarterly earnings. The results showed that accounting earnings and accruals have incremental information content over operating cash flows in accessing future financial performance.

Senan (2019) examined the capability of current income and operating cash flows and disaggregation of income to predict the future operating cash flows. A direct association was found between earnings and future cash flows. Further, it was reached that the disaggregation of income into accruals has a greater information content of forecasting future operating cash flows, while disaggregated earnings into other accrual components have decreased the predictive power. Frankel and Sun (2018) wanted to understand the extent to which cash-flow properties explain accruals. Using the Dechow et al. (1998) model, a negative relation was derived between accruals changes. It was shown that the strength of the relation is linked to a negative serial correlation in cash-flow changes.

Ragab and Hani (2018) tested if the value content of cash flows from operating activities varies between banks listed in Egypt and Lebanon. The study used modified Ohlson's model. It was found that operating cash flows are positively and significantly related to stock prices and that earnings had a higher information content than operating cash flows. Jemaa et al. (2015) tested the account- ing earnings ability versus operating cash flows to predict future operating cash flows in the Tunisian context. The results showed that cash flows from operating activities have the most forecasting capacity. On the other hand, for multi-year models, earnings are the most relevant in terms of the forecasting ability of future cash flows. Mostafa and Dixon (2013) examined the predictive ability to operate cash flows and earnings and the impact of extreme income on the predictive ability of cash flow from operations in UK companies. The findings showed that both cash flow from operating activities and earnings have incremental information content beyond each other.

Pouraghajan et al. (2012) evaluated the incremental and relative information content of cash flows from operating activities and earnings in the listed firms on the Tehran Stock Exchange. Moreover, the study investigated the loss effect on the information content of flows from operating activities and earnings. The findings indicated that income has more predictive ability than cash flows from operating activities in explaining stock returns. Arnedo et al. (2012) determined whether earnings have information value beyond that provided by isolated current operating cash flows for the prediction of future operating cash flows using a sample of 4,397 Spanish firms.

Market prices reflect investor predictions about future cash flows, which requires estimating future profits based on current information. In this regard, cash flows are the focus of attention of investors, who are more interested in the cash that can be collected than the profits that can be realized (Dechow, 1994). While there is an agreement about the importance of forecasting cash flows, there is a disagreement about the appropriate method for predicting future cash flows and the accounting information that can be a good indicator of future cash flows. Accruals are among the items that have been relied upon to improve models for forecasting future cash flows. Accruals are expected to contribute to improving cash flows as a measure of the company's performance, despite the application of the revenue recognition principle and the matching principle (Beaver, 1998). However, accruals allow part of the past and future cash flows to be incorporated into profit, thus solving the matching and timing problems. 
Therefore, adding the accounting accruals to the forecasting models generates additional predictive power of future cash flows (Guay \& Sidhu, 2001).

The accounting accruals are among the most important items that reflect future cash flows, as they are adjustments to current cash flows - they are either cash flows related to a past period (or periods), or they are cash flows related to a future period (or periods), and thus they are latent cash flows. However, a distinction should be made between long-term and short-term accounting accruals, the latter being expected to be more suitable for forecasting future cash flows, because they are related to operational processes, which represent the main activity of the company, and are continuous and recurring (Ragab \& Hani, 2018).

The purpose of the study is to explore the ability of short-term accounting accruals to predict future operating cash flows. This study aims to explore the Jordanian industrial companies' ability to predict cash flows using short-term accounting accruals. It allows users, and especially investors, to understand the determinants of cash flow. This study was conducted for evaluating the predictive ability of future operating cash flows by using accounting earnings and current cash flows information.

Based on previous studies, it is possible to say that accounting accruals have a significant impact on future cash flows due to the relevance of this information and its confirmability and predictability. Previous studies have indicated that the size of firms is an additional factor influencing the information content of accruals and operating cash flows. Investors can therefore put higher trust in large firms. Charitou et al. (2000) showed that cash flows have incremental information content beyond earnings in explaining security returns, and that cash flows play a more vital role in the marketplace when earnings are transitory. Dimitropoulos et al. (2010) indicated that the role of size is controversial due to unclear findings on the nature of the effect of size on the association between operating cash flows and accounting accruals.

Therefore, the study hypotheses can be posited as follows:
H1: Accounting accruals can predict the future operating cash flow.

H2: The size of the company has a moderating effect on the relationship between accounting accruals and operating cash flow.

\section{METHODOLOGY}

\subsection{Empirical model}

To test the hypotheses of the study, a statistical model was relied upon largely based on the Arnedo et al. (2012) model, which distinguishes between five components of accounting accruals, where the result can be expressed by equation (1):

$$
\begin{aligned}
& N I_{t}=O C F_{t}+\Delta I N V_{t}+\Delta A R_{t}- \\
& -\triangle A P_{t}-\Delta O C L_{t}-D E P_{t},
\end{aligned}
$$

Therefore, operating cash flow can be calculated using equation (2) as follows:

$$
\begin{aligned}
& O C F_{t}=N I_{t}-\Delta I N V_{t}-\Delta A R_{t}+ \\
& +\triangle A P_{t}+\Delta O C L_{t}+D E P_{t},
\end{aligned}
$$

where $O C F_{t}$ - operating cash flows in a year $(t)$; $N I_{t}$ - net income in a year $(t) ; \Delta I N V_{t}$ - change in inventory in a year $(t) ; \Delta A R_{t}$ - changes in account receivable in a year $(t) ; \triangle A P$ - changes in accounts payable in a year $(t) ; \triangle O C L_{t}$ - changes in other current liabilities in a year $(t) ; D E P_{t}$ - depreciation expense in a year $(t)$.

As shown from equation (2), operating cash flow can be determined from net income, short term accounting accruals $(\triangle I N V, \triangle A R, \triangle A P, \triangle O C L)$, and long term accounting accruals $(D E P)$. Therefore, the study model will be in a multiple regression form that relates future operating cash flow as a dependent variable with net income and accruals' five components as independent variables:

$$
\begin{aligned}
& O C F_{i t+1}=\alpha_{0}+\alpha_{1} O C F_{i t}+\alpha_{2} N I_{i t}+ \\
& +\alpha_{3} \Delta A R_{i t}+\alpha_{4} \Delta I N V_{i t}+\alpha_{5} \Delta A P_{i t}+ \\
& +\alpha_{6} D E P_{i t}+\alpha_{7} O T H_{i t}+\varepsilon_{i t}
\end{aligned}
$$

where $O C F_{i t+1}$ - operating cash flows for company (i) in year (t+1); OTH OTt $_{i t}$ oth- 
er accounting accruals for company (i) in a year $(t)$, and it will be computed as follows: $O T H=N I-(C F+\triangle A R+\Delta I N V+\triangle A P-D E P)$; $\alpha_{0}$ - the equation constant; $\alpha_{1}, \alpha_{2}, \alpha_{3}, \alpha_{4}$, $\alpha_{5}, \alpha_{6}, \alpha_{7}$ - variables coefficients; $\varepsilon_{i t}-$ model residuals, It is that part of the future operating cash flows that cannot be explained from the independent variables of the study model.

The paper provides several diagnostic checks for the impact of size on the ability of accruals in predicting future cash flow.

\subsection{Sample}

The study sample includes all industrial firms listed on the Amman Stock Exchange during the period 2006-2019. The total number of listed industrial companies on the Amman Stock Exchange for the entire study period was 77 companies. The study excludes insurance and financial firms because they are subject to special regulations. Data required to compute all study variables as well as control variables must be available for at least two consecutive years to include the firm in the statistical analysis. Applying these criteria has resulted in excluding only 1 firm. The total number of observations is 762 . 18 observations that represent outliers are excluded from the analysis.

\section{RESULTS}

The ordinary least squares method was used. It was ensured that the regression conditions are met, which are homoscedasticity, normality, linearity, and no autocorrelation using Durbin-Watson test. The variance inflation factor was used to test for multicollinearity. To test the hypotheses, the study utilized the following statistics: the adjusted $R^{2}, F$-statistic, and the t-statistic with its associated $p$-values. The statistical analysis software package (SPSS) version 22 was used.

Table 1 indicates descriptive measures for the main variables of the study. The mean and median values of current and future cash flows are higher than the mean and median values of accrual income, which indicates that accrual-related modifications (such as depreciation) decrease income but do not decrease cash flows.

In addition, the mean values of earnings and operating cash are positive and the standard deviation of earnings is lower than the standard deviation of operating cash flows. These findings are consistent with Aldebie (2011), and Dechow et al. (1998).

It is clear from the lower and upper limits that there are positive and negative values for all the explanatory variables, which means that there is fluctuation in the variables of the study between different periods and different companies.

It is also clear that the data distribution is expected to be close to the normal distribution for all variables, due to the presence of convergence between the mean and the median for each variable; returning to the standard deviation compared to the range, it turns out that there is no significant dispersion in the data.

The correlation coefficient matrix, as indicated in Table 2, varies from -0.55 to 0.930 . The variance inflation factor (VIF) was computed for the two models. The VIF varies between 3.244 and

Table 1. Descriptive measures

\begin{tabular}{|c|c|c|c|c|c|c|}
\hline Measure & Observations & Mean & Median & Standard deviation & Min & Max \\
\hline $\mathrm{OCF}_{i t+1}$ & 762 & $5,393,200$ & 334,757 & $26,776,287$ & $-446,020,000$ & 310878000 \\
\hline $\mathrm{OCF}_{\text {it }}$ & 762 & $5,436,412$ & 408,487 & 26731289 & -44602000 & 310878000 \\
\hline $\mathrm{NI}_{\text {it }}$ & 762 & 3834632 & 75137 & 26029092 & -88821000 & 310878000 \\
\hline$\Delta \mathrm{AR}_{\mathrm{it}}$ & 762 & 1825580 & -4198 & 10556896 & -113506000 & 15045000 \\
\hline$\Delta I N V_{i t}$ & 762 & -120665 & 0 & 8854363 & -110544000 & 119467000 \\
\hline$\triangle \mathrm{AP}_{\text {it }}$ & 762 & 96024 & 2321 & 6690065 & -98706287 & 65945000 \\
\hline $\mathrm{DEP}_{\text {it }}$ & 762 & 2198413 & 337983 & 8003270 & 0 & 70369000 \\
\hline $\mathrm{OTH}_{\mathrm{it}}$ & 762 & 630766 & 24 & 12397542 & 0 & 276188 \\
\hline Sales $_{\text {it }}$ & 762 & 37244246 & 8342239 & 108340513 & 0 & 846891895 \\
\hline
\end{tabular}


Table 2. Correlation matrix

\begin{tabular}{|c|c|c|c|c|c|c|c|c|}
\hline Variable & $\mathrm{OCF}_{\mathrm{it}}$ & $\mathrm{NI}_{\mathrm{it}}$ & $\Delta A R_{i t}$ & $\Delta \mathrm{INV}_{\mathrm{it}}$ & $\Delta A P_{i t}$ & DEP $_{i t}$ & $\mathrm{OTH}_{\mathrm{it}}$ & Sales $_{i t}$ \\
\hline $\mathrm{OCF}_{\mathrm{it}+1}$ & $0.798^{* *}$ & $0.782^{* *}$ & 0.056 & 0.062 & 0.068 & $0.71^{* *}$ & $0.325^{* *}$ & $0.676^{* *}$ \\
\hline $\mathrm{OCF}_{\text {it }}$ & & $0.930 * *$ & $0.091^{*}$ & $0.137^{* *}$ & 0.055 & $0.790^{* *}$ & $0.161^{* *}$ & $0.787^{* *}$ \\
\hline $\mathrm{NI}_{\mathrm{it}}$ & & & $0.187^{* *}$ & $0.222^{* *}$ & 0.006 & $0.680^{* *}$ & $0.218^{* *}$ & $0.704^{* *}$ \\
\hline$\Delta \mathrm{AR}_{\mathrm{it}}$ & & & & $0.180^{* *}$ & $0.431^{* *}$ & 0.005 & $-0.55^{* *}$ & $0.167^{* *}$ \\
\hline$\Delta I N V_{i t}$ & & & & & $0.446^{* *}$ & 0.005 & $-0.44^{* *}$ & $0.132 * *$ \\
\hline$\triangle A P_{i t}$ & & & & & & 0.042 & $-0.226^{* *}$ & $0.134^{* *}$ \\
\hline $\mathrm{DEP}_{\text {it }}$ & & & & & & & $0.363^{* *}$ & $0.817^{* *}$ \\
\hline $\mathrm{OTH}_{\mathrm{it}}$ & & & & & & & & $0.145^{* *}$ \\
\hline
\end{tabular}

Note: * means significant at the 0.05 level; ** means significant at the 0.01 level.

4.518. Therefore, there is no multicollinearity in the study regression models (Ahmed et al., 2021). Table 2 indicates a strong and significant relationship between current and future cash flow (0.798) and between earnings and future cash flows (0.782), which is an indication of the superiority of current cash flows over current accruals income in estimating future cash flows.

The results of the correlation are considered preliminary and cannot be relied upon to issue a final judgment about the hypotheses of the study, due to the presence of certain levels of correlation between the explanatory variables that would affect their relationships with the dependent variable.

\section{DISCUSSION}

The results of the analysis of variance of the study model are based on the financial statements of the Jordanian industrial companies. Fisher test was significant at the level of $1 \%$, which necessarily means that the study model is significant, so one of the regression coefficients of this model is at least significant and differs from zero fundamentally. Thus, there is a statistically significant relationship between the dependent variable and at least one of the independent variables, and that at least one of the independent variables contributes to explaining the changes that affected the dependent variable during the study period.

Tables 3 and 4 report the study model's coefficient results. The independent variables can explain $69.3 \%$ of the variation of future cash flows. This means that the explanatory variables rep- resented in accounting accruals explain an estimated $69.3 \%$ of the changes that affected the future net operating cash flows during the study period, while the rest of the changes are due to other factors and random errors.

In addition, F-test is significant, so $\mathrm{H} 1$ is accepted; therefore, accounting accruals can predict the future operating cash flow.

For the accrual components, only the change in accounts payable is not significant but the other variables (current operating cash flow, net income, change in accounts receivable, change in inventory, depreciation, and other accruals) have a strong positive correlation with future cash flows. The depreciation coefficient was significant with a $90 \%$ confidence level.

The results of estimating the study model also showed that there is no significant relationship between the change in the accounts of suppliers and creditors for the current period and the net operating cash flows for the next period. As for the relationship of net operating cash flows for the next period with other short-term accounting accruals, it was significant, which means that the contribution of accounting accruals is long. The term for the current period in forecasting the operating cash flows for the coming period in the Jordanian industrial companies is strong.

For H2, Table 4 indicates that company size (sales) does not have incremental information content over earnings accrual in predicting future cash flows because there is no increase in Adj $\mathrm{R}^{2}$ and the control variable coefficient is not significant. 
Table 3. Hypothesis 1

\begin{tabular}{|c|c|c|c|c|}
\hline Variable & Coefficient & Error & $\mathbf{t}$ & Sig \\
\hline Equation Constant & 80 & 55 & 1.433 & 0.152 \\
\hline $\mathrm{OCF}_{\text {it }}$ & 0.677 & 0.034 & 19.957 & 0 \\
\hline $\mathrm{NI}_{\text {it }}$ & 0.484 & 0.165 & 2.928 & 0.004 \\
\hline$\triangle \mathrm{AR}_{\text {it }}$ & 0.377 & 0.072 & 5.271 & 0 \\
\hline$\Delta I N V_{\text {it }}$ & 0.223 & 0.080 & 2.792 & 0.005 \\
\hline$\Delta \mathrm{AP}_{\text {it }}$ & 0.004 & 0.101 & 0.036 & 0.971 \\
\hline$D P_{\text {it }}$ & 0.204 & 0.121 & 1.689 & 0.092 \\
\hline $\mathrm{OTH}_{\text {it }}$ & 0.664 & 0.068 & 9.834 & 0 \\
\hline$R^{2}$ & 0.695 & \multicolumn{2}{|c|}{ Adj $R^{2}$} & 0.693 \\
\hline F-Statistics & 287.184 & \multicolumn{2}{|c|}{ Sig. } & 0 \\
\hline VIF & 3.244 & \multicolumn{2}{|c|}{ Durbin-Watson } & 2.151 \\
\hline
\end{tabular}

Table 4. Hypothesis 2

\begin{tabular}{|c|c|c|c|c|}
\hline Variable & Coefficient & Error & $\mathbf{t}$ & Sig \\
\hline Equation Constant & 61 & 57 & 1.066 & 0.287 \\
\hline$O C F_{i t}$ & 0.657 & 0.036 & 18.083 & 0 \\
\hline $\mathrm{NI}_{\text {it }}$ & 0.441 & 0.173 & 2.550 & 0.011 \\
\hline$\Delta \mathrm{AR}_{\mathrm{it}}$ & 0.365 & 0.072 & 5.064 & 0 \\
\hline$\Delta I N V_{i t}$ & 0.221 & 0.080 & 2.772 & 0.006 \\
\hline$\triangle A P_{\text {it }}$ & -0.005 & 0.101 & -0.054 & 0.957 \\
\hline $\mathrm{DEP}_{\text {it }}$ & 0.091 & 0.143 & 0.636 & 0.525 \\
\hline $\mathrm{OTH}_{\text {it }}$ & 0.671 & 0.068 & 9.925 & 0 \\
\hline Sales $_{\text {it }}$ & 0.015 & 0.010 & 1.501 & 0.134 \\
\hline$R^{2}$ & 0.696 & \multicolumn{2}{|c|}{ Adj $R^{2}$} & 0.693 \\
\hline F-Statistics & 246.888 & \multicolumn{2}{|c|}{ Sig. } & 0 \\
\hline VIF & 4.518 & \multicolumn{2}{|c|}{ Durbin-Watson } & 2.155 \\
\hline
\end{tabular}

The compatibility of the results of this study with the results of many previous studies can be traced back to the similarity concerning the uses of accounting information and concerning the main users of it, which resulted in the agreement of the factors explaining the cash flows. In addition to paying attention to information about cash flows and their estimates for Jordanian companies, the evidence for this is that Jordanian companies were preparing a statement of cash flows before 1998.

\section{CONCLUSION}

This paper aims to explore the accounting accruals' ability to predict future cash flows. It included 762 observations from 2006 to 2019, which concern 77 Jordanian industrial firms. Cash flows have been measured by cash flow from operating activities. In addition, accounting accruals have been expressed by change of inventories, change of accounts payable, and change of accounts receivable.

The study focused to explore the extent to which short-term accounting accruals can predict cash flows (operating cash flows), and the following are the most important conclusions and recommendations of the study.

The study results show that the change in accounts payable cannot predict the future cash flows because the accounts payable turnover does not exceed one period and thus it can not be relied on explaining the future cash flow variation. The informative content of accruals and operating cash flow is not a 
closed subject, since previous studies showed conflicting evidence and environment specificity for the role played by each measure. The inconsistency of the findings of this study with the results of previous studies can be attributed to the differences that exist between the Jordanian environment and other economic environments about the uses of accounting information and the main users of it, which resulted in different factors explaining cash flows.

The study recommends that these results require future studies. It is necessary to use other accounting items to predict future cash flows, such as other long-term accounting accruals items, sales level, purchases level, and using control variables that can increase the predictive power of the model used, such as activity level, performance level, and financial leverage.

\section{AUTHOR CONTRIBUTIONS}

Conceptualization: Mohammad Fawzi Shubita.

Data curation: Mohammad Fawzi Shubita.

Formal analysis: Mohammad Fawzi Shubita.

Funding acquisition: Mohammad Fawzi Shubita.

Investigation: Mohammad Fawzi Shubita.

Methodology: Mohammad Fawzi Shubita.

Project administration: Mohammad Fawzi Shubita.

Resources: Mohammad Fawzi Shubita.

Software: Mohammad Fawzi Shubita.

Supervision: Mohammad Fawzi Shubita.

Validation: Mohammad Fawzi Shubita.

Visualization: Mohammad Fawzi Shubita.

Writing - original draft: Mohammad Fawzi Shubita.

Writing - review \& editing: Mohammad Fawzi Shubita.

\section{ACKNOWLEDGMENTS}

I would like to thank Amman Arab University for its great support, and for funding this study.

\section{REFERENCES}

1. Ahmed, W., Khan, H. H., Rauf,

A., Ulhaq, S., Bano, S., Sarwar,

B., \& Durrani, M. N. (2021).

Simultaneous equation estimation in finance and corporate financial decision: Empirical evidence from Pakistan stock exchange. The Journal of Asian Finance, Economics, and Business, 8(3), 11-21. https://doi.org/10.13106/ jafeb.2021.vol8.no3.0011

2. Al Sharawi, H. (2021).

Earnings versus cash flows in predicting future cash flows: Evidence from Egypt and KSA. Alexandria Journal of Accounting Research, 5(1), 714-743. https://doi.org/10.21608/ALJALEXU.2021.162518
3. Al-Debie, M. M. (2011). Working capital management and profitability: the case of industrial firms in Jordan. European Journal of Economics, Finance and Administrative Sciences, 36, 75-86. Retrieved from https://silo. tips/download/working-capitalmanagement-and-profitability-thecase-of-industrial-firms-in-jor

4. Aldebie, M. A. M. (2011). Is operating cash flows a superior predictor of future operating cash flows than earnings? Evidence from Jordan. European Journal of Economics, Finance and Administrative Sciences, 40, 36-46.

5. Arnedo, L., Lizarraga, F., \& Sánchez, S. (2012). The role of accounting accruals for the prediction of future cash flows: Evidence from Spain. SERIEs, 3(4), 499-520. https://doi. org/10.1007/s13209-011-0070-7

6. Beaver, W. H. (1998). Financial reporting: An accounting revolution (3rd ed.). Upper Saddle River, NJ: Prentice-Hall.

7. Board, J. L. G., \& Day, J. F. S. (1989). The information content of cash flow figures. Accounting and Business Research, 20(77), 3-11. https://doi.org/10.1080/00014788. 1989.9729389

8. Charitou, A., Clubb, C., \& Andreou, A. (2000). The value relevance of earnings and cash flows: Empirical evidence for 
Japan. Journal of International Financial Management \& Accounting, 11(1), 1-22. https://doi. org/10.1111/1467-646X.00053

9. Dambra, M. J. (2018). Stakeholder conflicts and cash flow shocks: Evidence from changes in ERISA pension funding rules. The Accounting Review, 93(1), 131-159. https://doi.org/10.2308/accr-51817

10. Dechow, P. M. (1994). Accounting earnings and cash flows as measures of firm performance: The role of accounting accruals. Journal of Accounting and Economics, 18(1), 3-42. https://doi.org/10.1016/01654101(94)90016-7

11. Dechow, P. M., Kothari, S. P., \& Watts, R. L. (1998). The relation between earnings and cash flows. Journal of Accounting and Economics, 25(2), 133-168. https://doi.org/10.1016/S01654101(98)00020-2

12. Dimitropoulos, P., Dimitrios, A., \& Evangelos, K. (2010): The relevance of earnings and cash flows in a heavily regulated industry: Evidence from the Greek banking sector. Advances in Accounting, 26(2), 290-303. https://doi.org/10.1016/j.adiac.2010.08.005

13. Efayena, O. (2015). The role of accrual accounting basis in the prediction of future cash flows: The Nigerian evidence. Research Journal of Finance and Accounting, 6(4), 171-180. Retrieved from https://www.iiste.org/Journals/index.php/RJFA/article/ view/19981/0

14. Frankel, R. M., \& Sun, Y. (2018). Predicting accruals based on cashflow properties. The Accounting Review, 93(5), 165-186. https://doi. org/10.2308/accr-52001

15. Godfrey, J. M., Hodgson, A., \& Holmes, S. (2003). Accounting theory $\left(5^{\text {th }}\right.$ ed.). Milton, Queensland: John Wiley \& Sons.

16. Greenberg, R. R., Johnson, G. L. \& Ramesh, K. (1986). Earnings versus cash flow as a predictor of future cash flow measures. Journal of Accounting, Auditing \& Finance, 1(4), 266-277. https://doi.org /10.1177/0148558X8600100402
17. Guay, W. R., \& Sidhu, B. K. (2001). The usefulness of long-term accruals. Abacus, 37(1), 110-131. https://doi.org/10.1111/14676281.00076

18. Habib, A. (2010). Prediction of operating cash flows: Further evidence from Australia. Australian Accounting Review, 20(2), 134-143. https:// doi.org/10.1111/j.18352561.2010.00086.x

19. Jemaa, O. B., Toukabri, M., \& Jilani, F. (2015). The examination of the ability of earnings and cash flow in predicting future cash flows: Application to the Tunisian context. Accounting and Finance Research, 4(1), 1-16. https://doi. org/10.5430/afr.v4n1p1

20. Kim, M., \& Kross, W. (2005). The ability of earnings to predict future operating cash flows has been increasing - not decreasing. Journal of Accounting Research, 43(5), 753-780. https://doi.org/10.1111/j.1475679X.2005.00189.x

21. Luc, P. T. (2018). The relationship between perceived access to finance and social entrepreneurship intentions among university students in Vietnam. The Journal of Asian Finance, Economics, and Business, 5(1), 63-72. https://doi. org/10.13106/jafeb.2018.vol5. no1.63

22. Machokoto, M., \& Areneke, G. (2021). Is the cash flow sensitivity of cash asymmetric? African evidence. Finance Research Letters, 38, 101440. https://doi. org/10.1016/j.frl.2020.101440

23. Mostafa, W., \& Dixon, R. (2013). The impact of earnings extremity on the information content of cash flow. Review of Accounting and Finance, 12(1), 81-104. https://doi. org/10.1108/14757701311295845

24. Nam, S., Brochet, F., \& Ronen, J. (2012). The predictive value of accruals and consequences for market anomalies. Journal of Accounting, Auditing \& Finance, 27(2), 151-176. https://doi. org/10.1177/0148558X11409149
25. Ngatimo, S., Dewi, S. C., \& Herosian, M. Y. (2021). Cash flow, financial leverage, and current ratio towards corporate value at food and beverage. Jurnal Mantik, 4(4), 2486-2493. https://iocscience. org/ejournal/index.php/mantik/ article/view/1143

26. Pimentel, R. C., \& Malacrida, M. J. C. (2020). Quarterly earnings, operating cash flow, and accruals in future performance assessment. BAR-Brazilian Administration Review, 17(4), 1-29. https://bar. anpad.org.br/index.php/bar/article/view/504

27. Pouraghajan, A., Emamgholipour, M., Niazi, F., \& Samakosh, A. (2012). Information content of earnings and operating cash flows: Evidence from the Tehran stock exchange. International Journal of Economics and Finance, 4(7), 41-51. https://doi.org/10.5539/ijef. v4n7p41

28. Ragab, N., \& Hani, E. C. (2018). The value-relevance of operating cash flow: Comparative study of banks listed on the Egyptian and Beirut stock exchanges. Academy of Accounting and Financial Studies Journal, 22(3), 1-12. Retrieved from https://papers.ssrn. $\mathrm{com} / \mathrm{sol} 3 /$ papers.cfm?abstract id $=3845199$

29. Senan, N. A. M. (2019). The ability of earnings and cash flows in forecasting future cash flows: A study in the context of Saudi Arabia. Academy of Accounting and Financial Studies Journal, 23(1), 1-13. Retrieved from https://www.researchgate. net/publication/331966648

30. Shubita, M. F. (2019). The impact of working capital management on cash holdings of large and small firms: Evidence from Jordan. Investment Management and Financial Innovations, 16(3), 76-86. https://doi.org/10.21511/ imfi.16(3).2019.08 